\title{
Trade liberalization and economic growth: the role of regulatory policies
}

\author{
Peter K. Biwott ${ }^{1}$, Eliud D. Moyi ${ }^{2}$, Dickson Khainga ${ }^{2}$ \\ ${ }^{1}$ Planning, Research and Policy Department, Kerio Valley Development Authority, Eldoret, Kenya \\ ${ }^{2}$ Macroeconomics Divisions, Kenya Institute for Public Policy Research and Analysis (KIPPRA), Nairobi, Kenya \\ Email address: \\ peterbiwott2009@yahoo.co.uk (P. K. Biwott), emoyi@kippra.or.ke(E. D. Moyi), edmoyi@yahoo.com(E. D. Moyi), \\ khainga@kippra.or.ke(D. Khainga)
}

\section{To cite this article:}

Peter K. Biwott, Eliud D. Moyi, Dickson Khainga.Trade Liberalization and Economic Growth: The Role of Regulatory Policies. Journal of World Economic Research. Vol. 2, No. 3, 2013, pp. 45-57. doi: 10.11648/j.jwer.20130203.13

\begin{abstract}
This paper investigates the relationship between international tradeliberalization and economic growth with a focus on the role of regulatorypolicies in a selected sample of sixteen sub-Saharan Africa (SSA) countries.While international trade liberalization refers to the removal ofbarriers to international trade, regulatory policies refer to the improvement ofcredit, labour and product markets in a country. Using panel data, the study applies the Instrumental Variables (IV) and the Generalized Method of Moments (GMM)methodologies to deal with the problem of endogeneity. The results show thatbetter regulatory policies significantly contribute to economic growth.Further, international trade liberalization works well when regulatory policiesare improved in tandem with liberalization. Thisimplies that less regulated countries benefit more from international tradeliberalization than heavily regulated countries. Therefore, improvements in policies that regulate credit, labour and product markets willenhance the gains from international trade liberalization in Sub-Saharan Africa. Further, the results show that accumulation of physical capital contributes to economic growth. Thus, Sub-Saharan African countries should reform their regulatory policies as they continue to deepen international trade liberalization.
\end{abstract}

Keywords: Economic Growth, International Trade Liberalization, Regulatory Policies

\section{Introduction}

Africa is the only continent in the world where economic performance has been poor and unsustainable. Sub-Saharan Africa's (SSA) average income of US\$540lags behind incomes in all other regions and is far lower than the global average of US\$4742 (see table 1).After long periods of economic decline, most SSA countries adopted trade liberalization policies to help in economic recovery efforts. Trade liberalization was initiated in the 1980s and extensively adopted in the 1990 s and continues to be deepened in the 2000s through regional integration. Whereas the liberalization process has helped to bolster the importance of trade in gross domestic product (GDP) in SSA, her shares in world trade remain low and declining. For instance, SSA's trade share in GDP rose from 54 per cent in the 1980 's to 66 per cent in the 2000's whereas hershare in world trade was 3 per cent in 1985 but fell to 2 per cent in 2000. In fact, in the 2000's, Africa's share of trade in GDP(at 66 per cent) stayed above the global average of 52 per cent.

It is surprising to note that since the process of trade liberalization began, not much economic growth performance has been achieved in SSA.Some studies (including Rodrik, 1998) argue that perhaps the reason why trade liberalization has not yielded much economic growth gains in SSA was because the countries undertook trade liberalization reforms grudgingly and did not focus much on improvingbusiness regulations, rule of law, infrastructure and macroeconomic stability. However, we observe in figure3 that SSA trade liberalization was accompanied by improvements in the regulatory environment.

This study investigates the role of the regulatory policies in the trade-growth nexus in SSA. Regulatory policies under study are credit market, labour market and business regulations. We postulate that the implementation of policies to improve the regulatory environment canimprove the gains from trade liberalization. In other words, trade liberalization may be a necessary but not sufficient condition for high economic growth performance. 


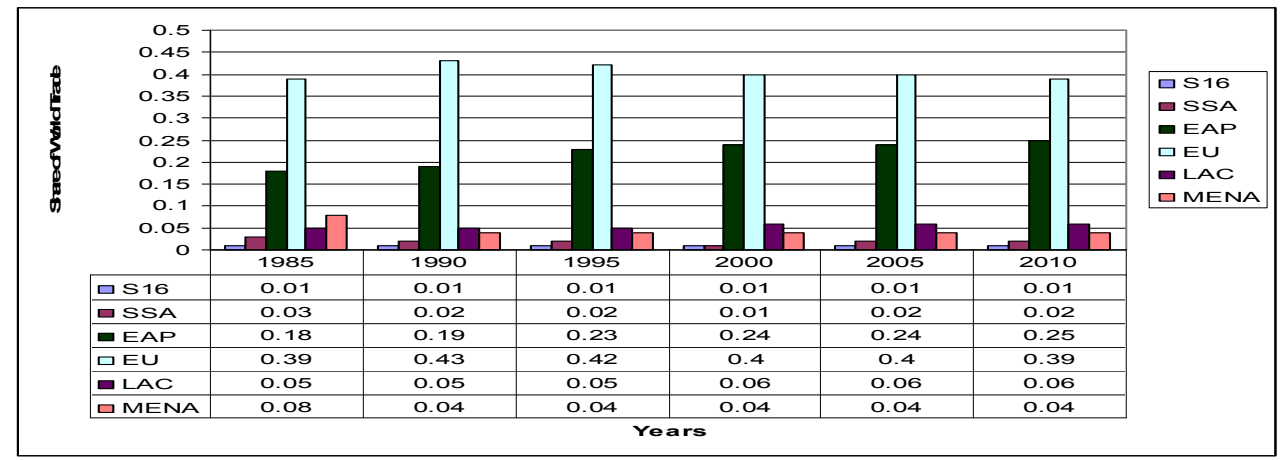

Source: Own construction using WDI 2010

Figure 1.Regional shares of world trade

\section{Comparative Economic Growth and Trade Performance}

This section reviews the performance of a sample of sixteen SSA countries (S16) and average performance of SSA, East Asia and Pacific (EAP), European Union (EU), Latin America and Caribbean (LAC), Middle East and North Africa (MENA) and the World. Tables 1 and 2, and figures 1 to 4 below show international trade and economic growth performance by the S16, SSA, EAP, EU, LAC, MENA and the World.

Table 1 show that between 1981 and 2010, average GDP per capita growth in SSA was 0.2 per cent and average per capita income was US\$540. The per capita income of SSA, a low income region, is the lowest in comparison to those of the World (US\$4,742), EAP (US\$3,473), EU (US\$15,206), LAC (US\$3,824) and MENA (US\$2,651). EAP experienced the highest average annual GDP per capita growth rate whereas SSA experienced the lowest. The trade share of GDP in SSA was about 59 per cent which was the third highest with the EU registering the second highest at 60 per cent and MENA recording the highest at 69 per cent. The S16 trade share of GDP stands at 61 per cent. This signifies the larger role that international trade plays in the S16 and SSA economies

Table 1.Economic Growth and Trade Averages 1981-2010

\begin{tabular}{|c|c|c|c|c|c|c|c|}
\hline Country & GDP Per Capita (US\$) & $\begin{array}{l}\text { GDP } \\
\text { capita } \\
(\%) \\
\end{array}$ & $\begin{array}{r}\text { per } \\
\text { growth }\end{array}$ & Trade/GDP (\%) & Exports/GDP (\%) & Imports/GDP (\%) & Status \\
\hline Benin & 324 & & 1 & 46 & 16 & 30 & Low \\
\hline Botswana & 2764 & & 5 & 98 & 53 & 45 & Middle \\
\hline CAR & 264 & & -1 & 43 & 21 & 26 & Low \\
\hline Ghana & 244 & & 1 & 65 & 26 & 39 & Low \\
\hline Kenya & 424 & & 0.2 & 58 & 28 & 32 & Low \\
\hline Malawi & 143 & & 0.2 & 61 & 25 & 36 & Low \\
\hline Mali & 222 & & 1 & 54 & 20 & 34 & Low \\
\hline Mauritius & 3106 & & 4 & 120 & 58 & 62 & Middle \\
\hline Nigeria & 375 & & 0.7 & 65 & 35 & 30 & Low \\
\hline Sierra Leone & 233 & & 0.2 & 47 & 20 & 27 & Low \\
\hline South Africa & 3230 & & 0.4 & 52 & 27 & 25 & Middle \\
\hline Tanzania & 196 & & 1 & 28 & 10 & 18 & Low \\
\hline Uganda & 216 & & 2 & 34 & 12 & 22 & Low \\
\hline Zambia & 372 & & -1 & 71 & 33 & 38 & Low \\
\hline S16 & 790 & & 1 & 61 & 27 & 34 & Low \\
\hline SSA & 540 & & 0.2 & 59 & 29 & 30 & Low \\
\hline World & 4742 & & 1 & 42 & 21 & 21 & Middle \\
\hline EAP & 3473 & & 3 & 42 & 22 & 20 & Middle \\
\hline EU & 15206 & & 2 & 60 & 30 & 30 & High \\
\hline LAC & 3824 & & 1 & 37 & 19 & 18 & Middle \\
\hline MENA & 2651 & & 1 & 69 & 35 & 34 & Middle \\
\hline
\end{tabular}

Source: Own construction using WDI 2010 
compared to other regions of the world. However, unlike other regions, imports share in GDP for SSA is higher than the relative export share.

Middle income countries in SSA include South Africa, Botswana and Mauritius with average income per capita of US\$3,230, US\$ 2,764 and US\$3,106 respectively. On the other hand, the trade shares of GDP on average shows that there are wider variations across individual countries. The trade share varies from the lowest at 28 per cent for Tanzania and the highest at 120 per cent for Mauritius. It is important to note that despite the deepening of trade liberalization effort in these countries, the S16 and SSA remain poor.Comparatively, all the other regions except the EU are all middle income regions as shown by table1.

Table 2 shows that the GDP per capita growth rates in S16 and SSA are low and they exhibit fluctuating trends. The SSA'sGDP per capita growth expanded from a paltry 1 per cent in the 1980 s to 2 per cent in the 2000s.In the 1980s and 1990s, SSA experienced the worst economic growth performance of all the regions of the world. Like SSA, the S16 countries also experienced a growth improvement from 0 to 2 per cent during the same period. Generally, it can be seen that the S16 and SSA do not exhibit sustainably high economic growth rates which is a prerequisite for economic development (see El-Erian and Spence, 2008). The global economic performance declined from 2 per cent in the 1980s to 1 in 2000s. Other regions that experienced declines in GDP per capita growth rates are the East Asia and Pacific and the EU. Like SSA, LAC and MENA experienced increases in GDP growth per capita. However, it is important to note that despite the improved GDP per capita growth in SSA during the three decades, GDP per capita level remain low relegating the region to a low income status. This maymean that the GDP growth experienced in SSA over the three decades has been counteracted by growth in population. Overall, per capita incomes in all the regions have been improving with the lowest being the S16 and SSA while EU is the highest.

The trade/GDP ratioin SSA improved from 54 per cent in the 1980 s to 66 per cent in the 2000 s whereas the trade/GDP ratio in the S16 increased from 56 to 62 per cent over the same period. All the regions' trade performance improved causing the aggregate world trade to increase from 37 per cent in 1980s to 52 per cent in the 2000s. Trade therefore, remains one of the key contributors to economic growth in the S16, SSA, the other regions and the world at large. The trend in performance of exports and imports can promote or inhibit economic growth performance. The S16 and SSA trade performance show that these countries are net importers of goods and services. On the contrary, EAP, EU, LAC and MENA are net exporters of goods and services. Whereas the exports and imports shares increased in the S16 and SSA as well as in the other regions, the imports share increased more than the export share in the S16 and SSA.

Table .2.Decadal Averages of Economic Growth and Trade Values

\begin{tabular}{|c|c|c|c|c|c|c|c|c|c|}
\hline \multirow[t]{2}{*}{ Countries/Regions } & \multicolumn{2}{|c|}{ GDP per capita (USD) } & \multirow[b]{2}{*}{ 2000s } & \multicolumn{3}{|c|}{ GDP Per Capita Growth Rate (\%) } & \multicolumn{3}{|c|}{ Trade/GDP (\%) } \\
\hline & $1980 s$ & 1990s & & 1980s & $1990 s$ & 2000s & $1980 s$ & 1990s & $2000 \mathrm{~s}$ \\
\hline Benin & 314 & 308 & 350 & 0 & 1 & 1 & 51 & 45 & 41 \\
\hline Botswana & 1704 & 2741 & 3846 & 8 & 3 & 3 & 119 & 93 & 40 \\
\hline CAR* & 306 & 253 & 244 & -2 & -1 & -1 & 53 & 40 & 36 \\
\hline Ghana & 208 & 234 & 290 & -1 & 1 & 3 & 26 & 63 & 107 \\
\hline Kenya & 427 & 421 & 425 & 1 & -1 & 1 & 56 & 59 & 60 \\
\hline Madagascar & 302 & 254 & 251 & -2 & -1 & 1 & 35 & 49 & 68 \\
\hline Malawi & 146 & 140 & 142 & -2 & 2 & 1 & 54 & 65 & 63 \\
\hline Mali & 191 & 201 & 274 & -1 & 2 & 3 & 49 & 57 & 55 \\
\hline Mauritius & 1929 & 3071 & 4317 & 3 & 4 & 3 & 112 & 127 & 122 \\
\hline Nigeria & 335 & 363 & 428 & -2 & 1 & 4 & 42 & 80 & 72 \\
\hline Sierra Leone & 273 & 200 & 224 & -1 & -5 & 6 & 42 & 44 & 54 \\
\hline South Africa & 3325 & 2993 & 3372 & 0 & -1 & 2 & 53 & 44 & 59 \\
\hline Tanzania & - & 263 & 326 & - & 0 & 4 & - & 52 & 32 \\
\hline Togo & 291 & 253 & 249 & -1 & 0 & -1 & 100 & 70 & 72 \\
\hline Uganda & 140 & 210 & 297 & 0 & 4 & 4 & 29 & 31 & 41 \\
\hline Zambia & 429 & 338 & 349 & -2 & -3 & 3 & 71 & 71 & 71 \\
\hline $\mathrm{SSA}^{*}$ & 552 & 505 & 562 & -1 & -1 & 2 & 54 & 56 & 66 \\
\hline S16 & 645 & 765 & 961 & 0 & 0 & 2 & 56 & 62 & 62 \\
\hline World & 4,234 & 4,872 & 5,715 & 2 & 2 & 1 & 37 & 42 & 52 \\
\hline EAP & 2,744 & 3,630 & 4,532 & 4 & 2 & 3 & 37 & 40 & 56 \\
\hline $\mathrm{EU}$ & 12,852 & 15,717 & 19,012 & 2 & 2 & 1 & 55 & 60 & 73 \\
\hline LAC & 3,586 & 3,880 & 4,487 & -1 & 2 & 2 & 31 & 40 & 46 \\
\hline MENA & 2,441 & 2,649 & 3,209 & -1 & 2 & 3 & 71 & 71 & 72 \\
\hline
\end{tabular}


Table 3.Continued: Decadal Averages of Economic Growth and Trade Values

\begin{tabular}{|c|c|c|c|c|c|c|}
\hline Countries/Regions & Exports/GDP (\%) & & & s/GDP & & \\
\hline & $1980 \mathrm{~s}$ & 1990s & $2000 \mathrm{~s}$ & $1980 \mathrm{~s}$ & $1990 \mathrm{~s}$ & $2000 \mathrm{~s}$ \\
\hline Benin & 17 & 16 & 14 & 34 & 29 & 27 \\
\hline Botswana & 62 & 51 & 45 & 57 & 42 & 37 \\
\hline CAR* & 20 & 16 & 15 & 33 & 24 & 21 \\
\hline Ghana & 11 & 25 & 43 & 15 & 38 & 65 \\
\hline Kenya & 26 & 28 & 25 & 31 & 31 & 34 \\
\hline Madagascar & 14 & 20 & 27 & 22 & 28 & 41 \\
\hline Malawi & 24 & 25 & 25 & 30 & 39 & 39 \\
\hline Mali & 16 & 21 & 23 & 34 & 36 & 32 \\
\hline Mauritius & 54 & 62 & 59 & 58 & 66 & 64 \\
\hline Nigeria & 22 & 42 & 42 & 20 & 38 & 31 \\
\hline Sierra Leone & 20 & 20 & 20 & 23 & 24 & 34 \\
\hline South Africa & 29 & 24 & 30 & 24 & 21 & 29 \\
\hline Tanzania & - & 16 & 14 & - & 36 & 18 \\
\hline Togo & 46 & 30 & 29 & 53 & 40 & 43 \\
\hline Uganda & 12 & 10 & 13 & 18 & 21 & 27 \\
\hline Zambia & 34 & 33 & 33 & 36 & 39 & 38 \\
\hline SSA* & 27 & 27 & 32 & 28 & 29 & 34 \\
\hline S16 & 25 & 27 & 29 & 30 & 34 & 36 \\
\hline worla & 19 & 21 & 26 & 19 & 21 & 26 \\
\hline LAT & 20 & 21 & 29 & 18 & 19 & 27 \\
\hline EU & 27 & 30 & 38 & 28 & 30 & 36 \\
\hline LAC & 17 & 19 & 24 & 15 & 21 & 22 \\
\hline 195 & 34 & 35 & 41 & 37 & 35 & 36 \\
\hline
\end{tabular}

Source: Own construction from WDI 2010.*SSA: Sub-Saharan Africa; CAR: Central Africa Republic

Exports-led economic growth achievement may improve rapidly economic growth performance in SSA. Morissey (2005) argues that exports performance in SSA has not brought sufficient economic growth even after the adoption of exports-led economic growth strategies. He therefore argues that SSA countries should improve domestic policies in order to ensure the export-led strategy is beneficial through expansion of exports volumes (ibid.).The S16 countries that acted as a source of economic growth in SSA by recording positive economic growth performance over the three decades include Benin, CAR, Ghana, Kenya, Madagascar, Malawi, Mali, Nigeria, Sierra Leone, South Africa, Tanzania, Togo, Uganda and Zambia. Botswana and
Mauritius recorded the highest but declining economic performance.

Figure 2shows the trends in the trade-GDP ratio and GDP per capita growth. Generally, the figure shows that trade and economic growth tend to move together. During the period 1980 to 1983 , the two variables fell. Between 1984 and 1988, both variables were abit volatile but generally increased. Between 1990/1992 and 2007, the variables were rising. This trend can be interpreted to mean that trade and economic growth complements each other. However, in 2008, the financial crisis hampered international trade and economic growth performance. 


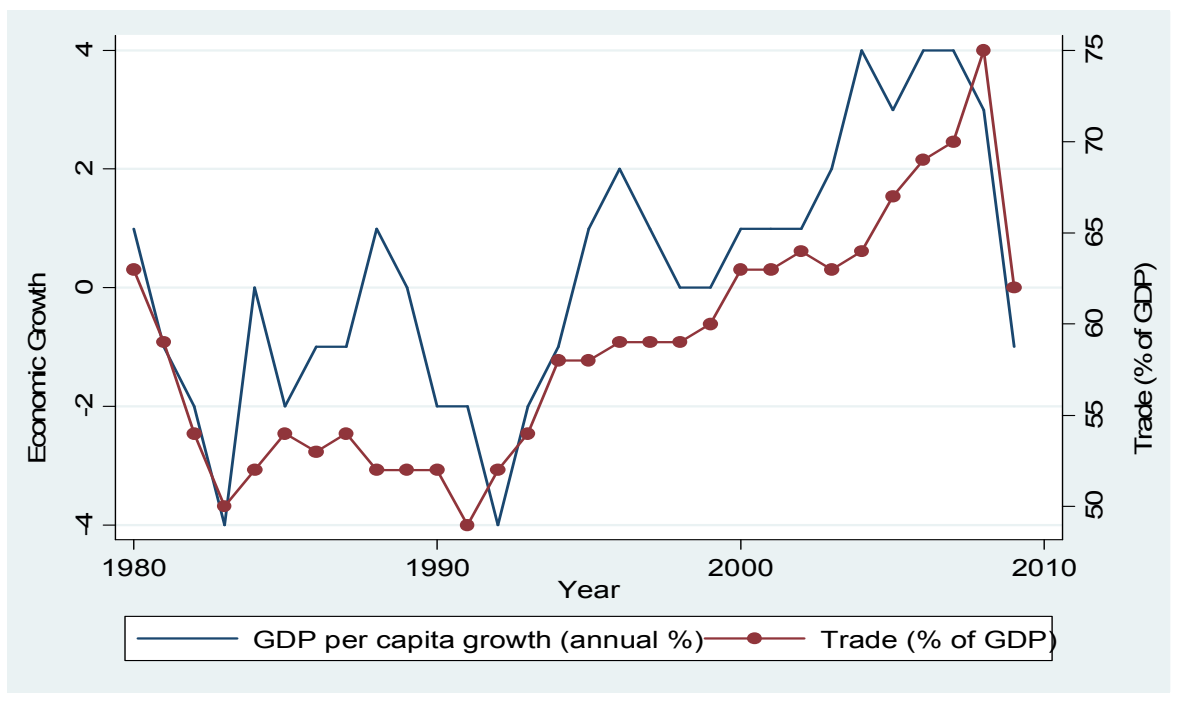

Source: Own construction from WDI data

Figure 2.Economic Growth and International Trade in SSA

Figure 3 compares international trade performance, GDP per capita growth and the regulations index in the S16, SSA, LAC, EAP, EU, and MENA between 1990 and 2010. In S16 and SSA, there were improvements in the trade share of GDP, trade policy index and regulations index between 1990 and 2010. However, the increases in the trade policy index and regulations index were faster than increases in the trade share of GDP. This may be interpreted to mean that although reforms in the areas of regulatory policies and trade liberalization were fast paced, the gains in trade came much slower. Perhaps this could be attributed to the fact that the effects of reforms are realized with a lag.

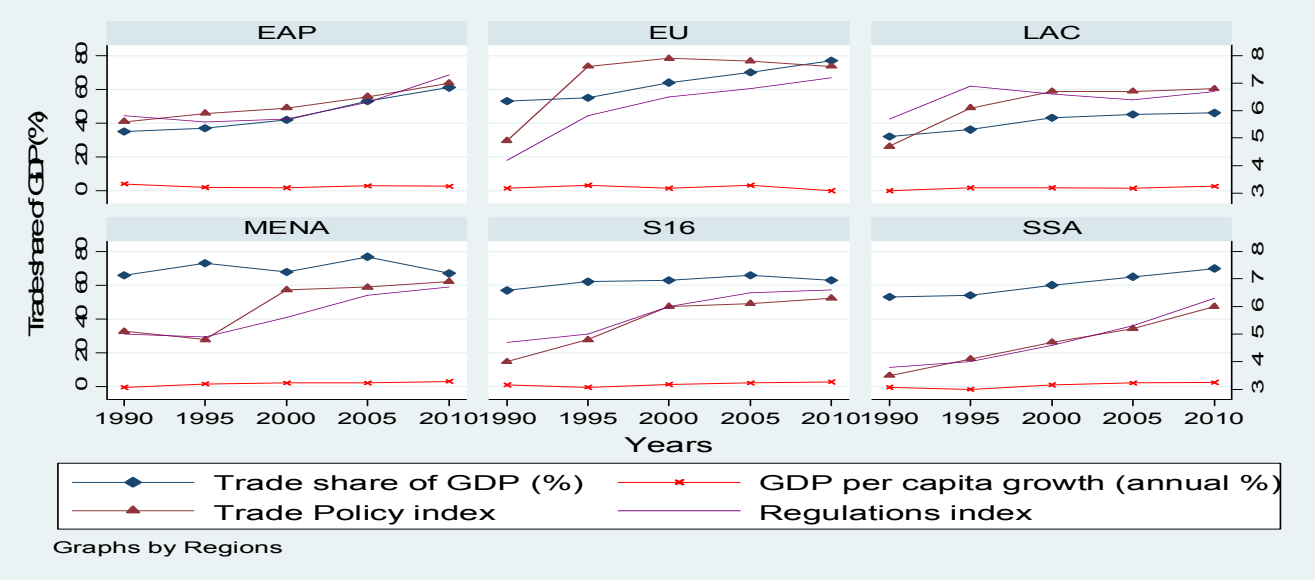

Source: Own construction from WDI and EFW data

Figure 3.Trade Liberalization, GDP per capita growth and Regulations

Unlike in S16 and SSA, the graphs for EAP, EU and LAC show that the trade policy index, trade share in GDP and regulations index are closely trending together. However, in MENA, the trade policy index and the regulations index are closely trending together but the trade share in GDP is abit volatile. We can conclude from this analysis that reforms in the trade and regulatory policies in EAP, EU and LAC were implemented simultaneously and this helped to improve their trade performance. However, in MENA, trade reforms and improvements in the regulatory policies did not benefit trade performance much.

\section{Theoretical and Empirical Literature}

\subsection{Theoretical Literature}

The study examines both the international trade and economic growth theories which underpins the importance of the determinants of economic growth such as international trade, human and physical capital 
accumulation and regulatory policies on economic development of low income countries. The theories of comparative advantage and Heckscher-Ohlin are the basis for which international trade liberalization was founded. They respectively explain international trade on the basis of costs and factor proportions implying that countries will respectively trade on goods and services they produce at low costs and based on their factor endowments. These theories postulate that developing countries trade in labour intensive products because they are endowed with abundant labour which lowers the opportunity costs of production. On the other hand, the developed countries specialize on capital intensive products due to their abundance of capital (see Ray, 1998, UNDP, 2003). The counterargument to the above postulations is the advancement of the infant industry and the new trade theories that advocates for a balance between international trade liberalization and protection to foster economic growth (Qiu, 1994, Krugman, 1983, 1987 and 1994).

On the other hand, growth theories that underpin the importance of international trade liberalization and therefore useful to this study are the Solow model and the endogenous growth theory (EGT). The Solowmodel (Solow, 1956) postulate that only changes in technological progress sourced externally has permanent economic growth effects. International trade therefore would play an important role in technological diffusion and progress from high to low income countries. Gundlach (2007) and Ray (1998) argue that international trade would lead to technological development and new skills transferred from developed to low income countries enhancing productivity and consequently economic growth performance. The Solow model accounts for convergence of similar countries to same levels of income (steady state) while the EGT accounts for long term economic growth phenomenon due to increasing returns to scale (Ray, 1998 and Romer, 1986, Romer, 1994).

The EGT postulates that long term improvements, for example, in international trade, regulatory policies and physical and human capital would generate high rates of economic growth performance for a longer period of time needed to achieve economic development. EGT focuses on generation of country specific technology and new skills augmented by those obtained internationally in the World stock of human and physical capital through international trade (Shaw, 1992). The interaction between local and foreign technology, skills and knowledge would breed unique innovations and inventions that are likely to generate high and sustainable rates of economic growth. Therefore, the Solow model and EGT are used in this study to investigate respectively the convergence situation and long term economic growth prospects of selected SSA countries. The theories therefore form the basis for the selection of the determinants of economic growth used in this study namely; international trade liberalization, regulatory policies and human and physical capital accumulation.

\subsection{Empirical Literature}

\subsubsection{International Trade Liberalization}

The quest for international trade liberalization emanated from the works of Little et al. (1970) and Balassa (1971) who strongly argued that the imports substitution industrialization (ISI) regime was the cause of developing countries' poor economic growth performance although Rodrik (2001) argued that it worked well prior to 1973 in countries including Swaziland, Botswana, Lesotho, Gabon, Togo and Kenya (ibid.). But, the World Bank (WB) and International Monetary Fund (IMF) called for policy shift from the ISI regime to international trade liberalization through the structural adjustment programmes (SAPs) (Rodrik 2001, UNDP, 2003 and Shafaeddin, 2005). As a result, the international trade liberalization regime was adopted in the $1980 \mathrm{~s}$, through the $1990 \mathrm{~s}$ and continues to be deepened in the 2000s. Babatunde (2009) and Ackah and Morrisey (2005) found that most SSA countries started adopting international trade liberalization early 1980s but a significant reduction of international trade barriers occurred in the 1990s. The achievement was, in part, achieved through participation in bilateral, regional and multilateral trading arrangements as found out by Nenci and Pietrobelli (2008) and Herz and Wagner (2011).

International trade liberalization contributes to economic growth in low income countries (Wacziarg and Welch, 2003, Sachs and Warner, 1995 and Ben-David and Loewy, 1998). Frankel and Romer (1999) found similar results although they argued that the link between trade and income was not strong. Ciuriak (2005) found out that trade liberalization improves exports through innovation and increased productive capacity. The finding contradictsDonmg and Whalley (2005) study on China which found that trade liberalization has little impact on exports.Krugman (1994), Vamvakidis (2001) and Yanikkaya (2002) findings are supportive of both international trade liberalization and protection. Apart from international trade liberalization being growth enhancing, they also established that its extent can have adverse effects on economic growth. Pak Hung (2011) argues that Africa experienced persistent economic declines despite international trade liberalization. Over half a century ago, best performing countries are those that liberalized partially, selectively and gradually, for example, the newly industrialized economies of East Asia who used long-term industrial policies (ibid.). Here, the pace and nature of international trade liberalization pursued is questioned. The justification for trade protection emanates from the infant industry arguments including at the multilateral trading negotiations at the World Trade Organization (WTO). The extent of international trade liberalization by either developing or developed countries is causing the discontents witnessed at the Doha Development Round of WTO trade negotiations (see Francois et al. 2005).

International trade liberalization contributions to economic growth are auxiliary according to Rodrik (1998). 
Greenaway et al. (2001) in their study using panel data established a weak relationship between international trade liberalization and economic growth due to the depth and intensity of international trade liberalization by the various countries. Rodriquez and Rodrik (2000) critiquing the works of Dollar (1992), Ben-David (1993), Sachs and Warner (1995) and Edwards (1998)-all who found that international trade liberalization is good for economic growth-argue that contribution of international trade liberalization on economic growth is inconclusive same to Ackah and Morrisey (2007) who suggest more empirical testing. Through their study which utilized GMM, they found that for poor countries, trade protection can be associated with high economic growth in the short term; that is, "the effect of protection on economic growth only becomes negative beyond some income threshold" (ibid.).

\subsubsection{Regulatory Policies}

Improvement of the regulatory environment to create efficient credit, labour and product markets stimulates economic growth (World Bank's Doing Business Reports). Busse and Groizard (2008) using panel data methodologies found that economic growth performance is high in less regulated or flexible economies due to expansion of local and foreign direct investments (FDI). This signifies the role of regulatory policies on increasing the rate of capital accumulation that aid in accelerating the pace of economic growth. Busse and Hefeker (2009) argue that flexible labour markets enhance the effects of international trade liberalization on economic growth. Moreover, findings by Djankovet al. (2006) using panel analysis show that improvement of business regulations accelerates the pace of economic growth (Baldwin, 2002). Stringent regulatory policies have been associated with deteriorating economic growth performance. Freund and Bolaky (2007) who used panel data found that better regulatory policies increases the effects of international trade liberalization on economic growth. The interaction between international trade liberalization and regulatory policies show that international trade liberalization increases incomes of countries with flexible economies unlike those with rigid economies (ibid.). Finally but not least, Schmidt and King (2005) argued international trade and foreign direct investments would be inhibited if countries do not create "appropriate and effective regulatory regimes" also in line with $\mathrm{Xu}$ and Wang (2007) findings concerning business environment in China. Improvement of regulatory regimes would thus foster prospects to achieve sustainable economic growth (ibid.).

\subsubsection{Physical capital accumulation}

Physical capital accumulation is one of the channels through which economic growth can be achieved. Winters (2004) argue that for international trade liberalization to bear long term high economic growth performance, combinations with accumulation of physical capital policies are needed. Wacziarg (2001) using panel models suggest a positive impact of international trade liberalization on economic growth with high contributions by capital accumulation and low effects experienced from technological development and macroeconomic stability. Serven and Solimano (1996) and Felipe et al. (2008) also demonstrated that promoting domestic and foreign capital accumulation leads to long term high economic growth performance. Countries with economic policy frameworks that inhibit capital accumulation diminish the benefits of international trade liberalization on economic growth (Hadjimichael and Ghura, 1996 and Rodrik, 2004). Ghosh (2007) and $\mathrm{Xu}$ and Wang (2007) argues that trade liberalization increases the flow of FDI accelerating the pace of economic growth in developing countries. Further, $\mathrm{Xu}$ and Wang (2007) find that the presence of FDIs creates more business opportunities for domestic investors, raises productivity levels of the economy and stimulate exports and facilitate acquisition of new technologies through imports.

\subsubsection{Human Capital Accumulation}

Human development index (HDI) is used as a proxy for human capital accumulation. Human development entails building peoples' capabilities to be knowledgeable, have high living standards and live longer. People of such capability can adapt and easily create new technologies postulated by EGT. According to Barro (1991), accumulating quality and quantity human capital lead to high economic growth performance. Davis and Guinlivan (2006) using GMM methodology found that trade improves human development. Further, Romer (1996), Barro (1991) and UNDP (2008) argues that creating a large pool of educated and healthy people increases possibilities of generation and adaptation of new technology that enhance productivity thereby stimulating economic growth. Similarly, Shaw (1992) argue that international trade liberalization exposes low income countries to the world stock of human capital which would contribute to high economic growth levels.

\section{Methodology}

\subsection{The Model}

$$
\begin{aligned}
& E G_{i, t}=\beta_{0}(E G)_{i, t-1}+\beta_{1}(C A P)_{i, t}+\beta_{2}(H D I)_{i, t} \\
& +\beta_{3}(P O L I C Y / O P E N)_{i, t}+\beta_{4}(R E G)_{i, t} \\
& +\beta_{5}\left(\text { POLICY /OPEN }{ }^{*} \varphi\right)+\mu_{i, t}
\end{aligned}
$$

The model adopted for this study follows the works of Romer (1994), Ray (1998), Chang et al 2006 and Freud and Bolaky (2007). The model is specified as follows ${ }^{1}$; Where;

\footnotetext{
1Interaction terms in the regression will help us to capture the marginal effects present between the differentexplanatory variables. Given $\mathrm{Y}=\mathrm{a}+\mathrm{bX}+\mathrm{cZ}+\mathrm{dXZ}+\mathrm{u}$, then $\mathrm{dY} / \mathrm{dX}=\mathrm{b}+\mathrm{dZ}$, which implies that the marginal effect of $\mathrm{X}$ on $\mathrm{Y}$ depends on $\mathrm{Z}$, where $\mathrm{d}$ captures the sign of this effect. If $\mathrm{d}$ and $\mathrm{b}$ are positive, it means that $\mathrm{Y}$ is increasing in $\mathrm{X}$ at a rate that is
} 
GDP per capita growth is denoted by $E G ; E G_{i, t-l}$ is the lagged EG; $C A P$ is the physical capital accumulation or investment; $H D I$ is the proxy for human capital accumulation; POLICY is the trade liberalization index; $O P E N$ is the outcome measure of trade liberalization; $R E G$ is the regulatory policies measure; POLICY/OPEN* ${ }^{*}$ represents the interaction between trade liberalization measures and regulatory policies variable; $\beta$ are the explanatory variables' coefficients; and "it" represents the number of cross sections and time periods in the panel.CAP is physical capital accumulation or investment. An increase in investment promotes economic growth due to the existing strong positive link. The S16 and SSA at large have their priorities directed at promoting local and foreign direct investments as way to improve the capacity to stimulate long term economic growth. Serven and Solimano (1996) and Felipe et al (2008) have demonstrated that promoting domestic and foreign investments leads to long term economic growth. Winters (2004) find that investment and other policies affecting investments stimulate long term economic growth. A poor investment environment reduces trade liberalization benefits on economic growth. Their results are also supported by Hadjimichael and Ghura (1996), Rodrik (1998) and Rodrik (2004). Accumulating a large stock of investments therefore increases possibilities of the S16 and SSA to achieve a high economic growth that would accelerate the pace of economic development.

$H D I$ is the proxy for human capital. Studies have shown that improvement of human capital exhibit a strong positive effect on economic growth. Barro (1991) argues that creating a large pool of educated people increases new ideas that can lead to the production of new goods and services thereby causing economic growth, partly through international trade. In addition, he argues that a highly educated country easily adapts to foreign new ideas and products as a result of international trade. Better education and health systems can be attained through formal and informal means. Vocational training and experience improves labourproductivity. The UNDP report (2008) cites Singapore's success, which was based on a high investment on human development polices. Singapore provided "universal healthcare and education, reasoning that a healthy and contented workforce would be more productive". The Republic of Korea invested in tertiary education, science and technology centres of excellence and linked university education with the needs of their export-led industrialization regime. Thus Singapore and Korea have achieved high income status.

$P O L I C Y$ is the trade liberalization index; OPEN is the outcome measure of trade liberalization. The study uses

increasing in $\mathrm{Z}$. If $\mathrm{d}$ is negative and $\mathrm{b}$ is positive, it means that $\mathrm{Y}$ is increasing in $\mathrm{X}$ at a rate that is decreasing in $\mathrm{Z}$. If $\mathrm{b}$ is negative and $\mathrm{d}$ is positive, it means that $\mathrm{Y}$ is decreasing in $\mathrm{X}$ at a rate that is increasing in $\mathrm{Z}$. both policy and outcome measures to examine the effects of trade liberalization. Trade in both consumption and capital goods can contribute to economic growth (Ben-David and Loewy, 1998; Saggi, 2002; Wacziarg and Welch, 2003). According to Jonsson and Subramanian (2001), trade enables a country to gain in four ways; (a) The country is able to employ a large variety of intermediate goods and capital equipment which would enhance the productivity of its other resources; (b) It is able to acquire technology developed worldwide, especially in the form of embodied capital goods; (c) trade increases the variety of products produced and consumed; and (d) trade improves the efficiency with which resources are used, which can help to change market structures and reduce mark-ups, thereby imparting dynamic efficiency benefits. But it is important to note that the effects of trade liberalization on economic growth are inconclusive (Greenaway, 2001; Morrisey and Ackah, 2007)

$R E G$ is the regulatory policies measure.Regulatory policies are an example of simultaneous policy used in this study. High and stringent regulatory barriers have been found to be a great hindrance to economic growth and development. A good investment environment has been associated with low cost of doing business that promotes economic growth. Freund and Bolaky (2007) who used panel data find that good regulatory policies make trade liberalization improve incomes. Trade liberalization increases incomes of countries with flexible economies unlike those with rigid economies (ibid.). Baldwin (2002) argues that trade liberalization process work well with a package of other policies such as better regulatory policies. Therefore, for trade liberalization to contribute more to economic growth, simultaneous polices should be part of the policy package.

\subsection{Variables and Data}

The description and measurement of the variables used in this study are presented in table 3 . The data was obtained from the World Development Indicators (WDI), UNDP's Human Development Reports (HDR), Penn World Tables (PWT) and Economic Freedom of the World (EFW) 2010 datasets. The data ranges from 1981 to 2010 aggregated in five year periods to reflect the long term growth characteristics ofEGTthrough increasing returns to scale assumptions. UNDP (2008) highlight that international trade gains are consolidated for a period of at least five years. The study focuses on S16 countries drawn partly from the East Africa Community (EAC), Common Market for Eastern and Southern Africa (COMESA), the Southern Africa Development Community (SADC) and Economic Community of West Africa States (ECOWAS). In addition, the selection is based on data availability, levels of incomes to draw a mix of strong and weak performers. The countries are Benin, Botswana, CAR, Ghana, Kenya, Madagascar, Malawi, Mali, Mauritius, Nigeria, Sierra Leone, South Africa, Tanzania, Togo, Uganda and Zambia. 
Table 3. Description of the Variables

\begin{tabular}{|c|c|}
\hline Variable & Description of Dependent and independent variables \\
\hline $\begin{array}{l}\text { EG (GDP per capita annual growth } \\
\text { rate) }\end{array}$ & The variable is the dependent variable and is a measure of a country's economic performance. \\
\hline $\begin{array}{l}\text { CAP (Gross Capital formation , \% } \\
\text { annual growth) }\end{array}$ & $\begin{array}{l}\text { Formerly gross domestic investment. This accounts for the accumulation of capital goods including } \\
\text { machinery and also the improvement of infrastructure. Capital accumulation is postulated to have a positive } \\
\text { effect on growth in endogenous growth model. }\end{array}$ \\
\hline HDI(Human Development Index) & $\begin{array}{l}\text { HDI is a composite measure developed to measure the broader view of development. It entails variables such } \\
\text { as life expectancy and literacy levels. HDI is used in this research to proxy for the endogenous growth } \\
\text { variable of human capital development. Accumulation of human capital has a positive effect on economic } \\
\text { growth. The HDI is derived from GDP, education and life expectancy indices as follows; } \\
\mathrm{HDI}=(\text { GDP index + Education Index + Life expectancy index)/3 }\end{array}$ \\
\hline POLICY(Trade Liberalization Index) & $\begin{array}{l}\text { The index best known as freedom to trade internationally is a construction that entails in part taxes on } \\
\text { international trade, and regulatory trade barriers that can hamper international trade flows. The index } \\
\text { measures how a country has progressed in trade liberalization. The index ranges between } 0 \text { and } 10.0 \text { is an } \\
\text { indicator of a restrictive trade regime. The higher the index is, the more a country has liberalized their trade } \\
\text { regimes and is postulated to improve economic performance of countries. The components of this index are; } \\
\text { Taxes on International Trade; Revenues from trade taxes (\% of trade sector); Mean Tariff rate; Standard } \\
\text { Deviation of tariff rates; Regulatory Barriers; Non-tariff trade barriers; Compliance costs of importing and } \\
\text { exporting; Size of trade sector relative to expected; Black market exchange rates; International capital market } \\
\text { controls; Foreign ownership/investment restrictions; Capital controls. } \\
\left.\text { POLICY }=\left\{\left(\mathrm{V}_{\max }-\mathrm{V}_{\mathrm{i}}\right) / \mathrm{V}_{\max }-\mathrm{V}_{\min }\right)\right\} 10 \text { where } \mathrm{V} \text { is the values of components constituting the index. }\end{array}$ \\
\hline REG(Regulatory policies) & $\begin{array}{l}\text { The index is referred to as Regulation of Credit, Labour and Business. It is a measure showing the regulation } \\
\text { of credit, labour market, and overall business or investment market. It is postulated here that a good domestic } \\
\text { market environment has a positive impact on economic growth because it makes trade liberalization benefits } \\
\text { abundant. The components of this index are; Credit market regulations; Ownership of banks; Foreign bank } \\
\text { competition; Private sector credit; Interest rate controls/negative real interest rates; Labour market } \\
\text { regulations; Hiring regulations and minimum wage; Hiring and firing regulations; Centralized collective } \\
\text { bargaining; Hours regulations; Mandated cost of worker dismissal; Conscription; Business regulations; Price } \\
\text { controls; Administrative requirements; Bureaucracy costs; Starting a business; Extra payments/bribes; } \\
\text { Licensing restrictions; Cost of tax compliance. } \\
\left.\text { POLICY }=\left\{\left(\mathrm{V}_{\max }-\mathrm{V}_{\mathrm{i}}\right) / \mathrm{V}_{\max }-\mathrm{V}_{\min }\right)\right\} 10 \text { where } \mathrm{V} \text { is the values of components constituting the index. }\end{array}$ \\
\hline
\end{tabular}

Source: WDI 2010, Penn World Tables, HDR 2009, and EFW Reports 1975-2009

\subsection{Panel Models}

Panel models are becoming widely used in policy analysis in the contemporary economic development discourse. In this study, we shall employ the IV and GMM methodologiesto dealwith endogeneity problems recurrent in macroeconomic studies especially those related to the study of international trade and economic growth. Frankel and Romer (1999) recognized the endogeneity problem and suggested the use of instrumental variables (IV) and dynamic models using geographical features that they claim do not correlate to income. But Rodriquez and Rodrik's (2000) response to Frankel and Romer's (1999) proposed remedy for endogeneity is that the instruments used are invalid since earthquakes, floods and droughts for example affect incomes. Roodman(2006) identifies two ways of solving endogeneity, namely, differencing the data to get rid of fixed effects and IV. Thus, the IV-2SLS and GMM are the preferred methodologies that are used to produce consistent estimation results by dealing with the endogeneity problem. This follows suggestions by Wooldridge (2001) that a lagged value of GDP per capita is used as an explanatory variable. GMM estimator was proposed by Arellano and Bond (1991) who used the lagged values of endogenous or predetermined explanatory variables in levels as instruments (ibid.).

\section{Interpretation of Results}

\subsection{Instrumental Variable (IV-2SLS) Results}

The IV-2SLS results show that capital accumulation and interactivevariables have a positive effect on economic growth among the S16 countries. With the IV-2SLS results, trade liberalization is not statistically significant regardless of the trade liberalization outcome measure used. But improvement of the regulatory policies enhances economic growth and increases the benefits of trade liberalization on economic growth. 
Table 4. IV-2SLS and GMM Results

\begin{tabular}{|c|c|c|c|c|c|c|c|c|}
\hline \multirow[t]{2}{*}{ Model } & \multicolumn{4}{|c|}{ Instrumental Variables (IV-2SLS) } & \multicolumn{4}{|c|}{ Generalized Method of Moments (GMM) } \\
\hline & {$[1]$} & [2] & [3] & [4] & [5] & {$[6]$} & [7] & {$[8]$} \\
\hline VARIABLES & EG & EG & EG & EG & EG & EG & EG & EG \\
\hline & & & & & 0.0652 & $0.267^{* * *}$ & 0.0968 & 0.131 \\
\hline $\mathrm{EG}_{-1}$ & & & & & $(0.134)$ & $(0.098)$ & $(0.133)$ & $(0.114)$ \\
\hline & 0.0618 & 0.0234 & $0.0864 *$ & $0.111 * *$ & $0.0618 * *$ & 0.00361 & $0.0714 *$ & $0.0975^{* *}$ \\
\hline CAP & $(0.042)$ & $(0.0523)$ & $(0.045)$ & $(0.0501)$ & $(0.029)$ & $(0.0489)$ & $(0.0366)$ & $(0.0446)$ \\
\hline & -2.566 & 2.309 & 0.23 & 1.368 & -2.145 & -0.0139 & -0.0352 & 0.83 \\
\hline HDI & $(3.263)$ & $(3.741)$ & $(2.887)$ & $(3.12)$ & $(2.922)$ & $(2.79)$ & $(2.478)$ & (2.6) \\
\hline $\mathrm{OPEN}_{-1}$ & $\begin{array}{l}0.0214 \\
(0.0191)\end{array}$ & $\begin{array}{l}-0.0524 \\
(0.0469)\end{array}$ & & & $\begin{array}{l}0.0178 \\
(0.0178)\end{array}$ & $\begin{array}{l}-0.0396 \\
(0.0413)\end{array}$ & & \\
\hline POLICY $_{-1}$ & & & $\begin{array}{l}-0.124 \\
(0.5)\end{array}$ & $\begin{array}{l}-1.295 \\
(0.861)\end{array}$ & & & $\begin{array}{l}0.0181 \\
(0.439)\end{array}$ & $\begin{array}{l}-1.01 \\
(0.912)\end{array}$ \\
\hline REG & $\begin{array}{l}0.778 * * * \\
(0.259)\end{array}$ & & $\begin{array}{l}0.834 * * * \\
(0.299)\end{array}$ & & $\begin{array}{l}0.700^{* *} \\
(0.281)\end{array}$ & & $\begin{array}{l}0.664^{*} \\
(0.363)\end{array}$ & \\
\hline POLICY*REG & & & & $\begin{array}{l}0.155^{* *} \\
(0.0617)\end{array}$ & & & & $\begin{array}{l}0.123^{*} \\
(0.0716)\end{array}$ \\
\hline OPEN*REG & & $\begin{array}{l}0.0106^{*} \\
(0.00559)\end{array}$ & & & & $\begin{array}{l}0.00919 \\
(0.00567)\end{array}$ & & \\
\hline CONSTANT & $\begin{array}{l}-3.733 * * * \\
(1.428)\end{array}$ & $\begin{array}{l}-0.159 \\
(1.259)\end{array}$ & $\begin{array}{l}-3.789 * * \\
(1.676)\end{array}$ & $\begin{array}{l}1.316 \\
(2.402)\end{array}$ & $\begin{array}{l}-3.435^{* * *} \\
(1.219)\end{array}$ & $\begin{array}{l}0.769 \\
(1.4)\end{array}$ & $\begin{array}{l}-3.555^{* * *} \\
(1.352)\end{array}$ & $\begin{array}{l}0.943 \\
(2.386)\end{array}$ \\
\hline Observations & 64 & 64 & 63 & 63 & 64 & 64 & 63 & 63 \\
\hline R-squared & 0.4764 & 0.4020 & 0.4771 & 0.4006 & 0.4785 & 0.4529 & 0.4710 & 0.4366 \\
\hline Diagnostic Tests & P-Values & & & & & & & \\
\hline Wald/F-Test & 0.0010 & 0.0080 & 0.0015 & 0.0046 & 0.0000 & 0.0012 & 0.0000 & 0.0006 \\
\hline Sargan test & 0.4698 & 0.0570 & 0.1920 & 0.2646 & & & & \\
\hline Hansen J Test & & & & & 0.4884 & 0.0425 & 0.2209 & 0.2810 \\
\hline
\end{tabular}

Level of Significance: ${ }^{* * *} \mathrm{p}<0.01,{ }^{* *} \mathrm{p}<0.05,{ }^{*} \mathrm{p}<0.1$; Hypothesis Ho: Instruments are Valid

Equations [3] and [4] shows that accumulation of capital contributes to economic growth since the results on CAP are positively significant. In addition, equations [1] and [3], show that a one per cent increase in the regulatory policies index enhances GDP per capita by $0.778^{2}$ per cent when the trade liberalization measure is used and 0.834 per cent when the trade policy measure is used. Further, the results show that better regulation enhances the effects of trade liberalization on economic growth. The interaction between trade liberalization policy and regulatory policies measure enhances economic growth. In equation [4], the interactive variable between trade policy and the regulatory barriers index (POLICY*REG) is positive and significant.

The positive coefficient on POLICY*REG and the negative coefficient on POLICY implies that GDP per capita decreases in POLICY at a rate that is increasing in REG. In addition, the interaction of trade liberalization outcome and regulatory barriers index (OPEN*REG) yields a positive and significant coefficient but the coefficient on OPEN is negative and insignificant. This result implies that OPEN does not have an independent effect on growth, rather, countries with better regulatory regimes gain significantly more from openness. The interaction shows that improving regulatory policies enhances the effects of

${ }^{2}$ Regulation index ranges between 0 and 10 indicating more regulated to less regulated environment respectively. trade liberalization on economic growth. This confirms the argument by Rodrik (1998) that trade liberalization in developing countries did not confer much growth benefits because they failed to undertake simultaneous policies.

\subsection{Generalized Method of Moments (GMM) Results}

The GMM results in equation [5], [7] and [8] are in line with the EGT that capital accumulation is a channel through which economic growth and development can be achieved by low income countries. The results show that the improvement of capital accumulation by a percentage point in half a decade can increase the GDP per capitagrowth by 0.0618 per cent when the trade liberalization outcome measure is used. The use of trade liberalization policy measure (see equations [7] and [8]) show that capital accumulation enhances GDP per capitagrowth by about 0.0714 and 0.0975 per cent.

Equations [5], [6], [7] and [8] also show the importance of better regulatory policies and the trade liberalization process on economic growth. Improving domestic regulations particularly those related to credit, labour and business positively and significantly enhance economic growth in low income countries. When the trade liberalization outcome measure is used, a one point increase inregulatory policies indexcontributes to economic growth by about 0.7 per cent. The interaction of the trade liberalization outcome and regulatory measures however is not significant although it has the expected positive sign in 
line with the EGT. On the other hand, when the trade liberalization policy measure is used, the coefficient on POLICY*REG is positive and significant. Thus, in equation 8 , the sign on POLICY is negative while the sign on POLICY*REG is positive. This implies that GDP per capita growth decreases in POLICY at a rate that is increasing in REG. The interaction between the trade policy and regulatory policies indeximproves the contribution of trade liberalization on economic growth.

The lagged value of economic growth $\left(E_{-1}\right)$ exhibits a positive effect which is significant only in equation [6] indicating that the S16 countries experience economic growth divergence. This implies that the S16 countries are growing far apart instead of catching up with each other.The results of IV-2SLS and GMM models have shown that trade liberalization alone does not improve the economic growth prospects of low income countries. However, when trade liberalization is implemented concurrently with the lowering of business regulatory barriers, the effects are beneficial.

\section{Conclusions and Policy Recommendations}

The study investigated the effects of trade liberalization and business regulations on economic growth in the S16 countries. The SSA region has been experiencing slow and sometimes stagnant economic growth performance in the world despite her continued efforts towards liberalizing trade. Today, SSA remains the most underdeveloped region in the world. It also contributes the smallest share to world trade. Capital accumulation was found to contribute to economic growth and development. Increase of local and foreign investments contributes to economic growth for example through employment and improvement of technology.

Trade liberalization policy and outcome measures were used in this study. When the trade liberalization measures were entered on their own in both the IV-2SLS and GMM versions of the regression equations, the results were either positive or negative but insignificant showing that there is no important role for trade liberalization in promoting growth in SSA. However, when the interactive variables (POLICY*REG; OPEN*REG) are introduced in the regressions, the signs of trade liberalization measures become negative but insignificant while the signs of the interactive variables are positive and significant. The results show that trade liberalization does not have an independent effect on growth, rather, countries with better regulatory regimes gain significantly more from trade liberalisation. Therefore, trade liberalization is a necessary but not sufficient condition for high and sustained economic growth performance. SSA countries need to focus not only on trade liberalization, but also on simultaneous policies such as creating better regulatory policies in their quest for sustained economic growth and development.

In addition, policies to improve accumulation of capital are encouraged as the S16 and SSA countries continue the trade liberalization process. The improvement of the simultaneous policies will ensure increased investments by both local and foreign investors. Therefore, this study has found out that the improvement of the regulatory policies can stimulate investments both local and international that will increase international trade. There is therefore need to create efficiency in the credit, labour and product markets. Credit market regulations should further be improved to foster more private sector participation both local and international. Better credit market regulations should ensure provision of sustainable and affordable credit to the private sector to foster local and foreign direct investments.

Labour market regulations also need to be further improved to create better working conditions for workers. This can be, for example, through the provision of capacity building opportunities through on the job training and sponsorship to high education levels at local and foreign universities. The better working conditions, in part, improve worker's productivity. In turn, this would lead to high and sustained economic growth performance that would eventually result in economic development among the S16 and SSA countries. Business regulations are critical in determining establishments and flow of investments within the S16 and SSA at large. The process of improvement of the business regulatory frameworks should be accelerated in the region to eliminate unnecessary regulations and retain and simplify business regulations on the basis of health, safety and the preservation of the environment (Doing Business, 2010).

The results of this study have found out that better regulatory policies first promotes economic growth and secondly enhances the effects of trade liberalization on economic growth. As the S16 and SSA countries seek to liberalize their economies further, they need to focus concurrently on the implementation of simultaneous policies such as creating better regulatory policies. This way, the regional quest to achieve sustainable economic growth and development would be feasible.

\section{References}

[1] Arellano, M. and Bond, S. (1991), "Some Tests of Specification for Panel Data:Monte CarloEvidence and An Application to Employment Equations", The Review of Economic Studies, Vol. 58, No.2, pp. 277-297

[2] Ashra, S. (2002), "Inflation and Openness: A Study of Selected DevelopingEconomies", Indian Council for Research and International Economic Relations Working Paper, No. 84, pp. 1-35.

[3] Babatunde, A.M. (2009), "Can Trade Liberalization Stimulate ExportPerformance inSub-Saharan Africa?",Babatunde, Journal of International and Global Economic Studies, 2(1), pp. 68-92. 
[4] Balassa, B. (1971), "Trade Policies in Developing Countries", The AmericanEconomic Review, Vol. 61, No. 2, pp. 178-187.

[5] Baldwin, R. (2003), "Openness and Growth: What is the Empirical Relationship", NBERWorking Paper,No. 9578, pp. $1-29$.

[6] Barro, R. (1991), "Economic Growth in a Cross Section of Countries", The QuarterlyJournal of Economics, Vol. 106, No. 2, pp. 407443.

[7] Baum, C. (2006), An Introduction to Modern Econometrics Using Stata. Texas, StataPress.

[8] Ben-David, D. and Loewy, M. (1998), "Free Trade, Growth and Convergence", Journalof Economic Growth, Vol. 3, pp. 143-170.

[9] Chang, R., Kaltani, L., and Loayza, N. (2005), “Openness Can be Good forGrowth: TheRole ofPolicy Complementarities", World Bank Policy Research Working Paper, WPS3763, pp. 1-39.

[10] El-Erian, M. and Spence, M. (2008), "Growth Strategies and Dynamics; InsightsfromCountryExperiences", World Economics, Vol. 9, No. 1, pp. 57-96.

[11] Felipe, J. Lavina, E. and Fan, E. (2008), “The Diverging Patterns of Profitability, Investment andGrowth of China and India during 1980-2003", World Development, Vol. 36, No. 5, pp. 1-35.

[12] Frankel, J. and Romer, D. (1999), "Does Trade Cause Growth?", The American EconomicReview, Vol. 89, No. 3, pp.379-399. Fortainer, Farbienne (2001) "FDI and Technology Transfer", in OECD (2001) The Costs and Benefits of FDI, Paris, OECD

[13] Freund, C., and Bolaky, B., (2007), "Trade, Regulation and Income", Journal of Development Economics, DEVEC01342, pp. 1-13.

[14] Gundlach, E. (2007), "The Solow Model in the Empirics of Growth and Trade",KeilInstitute for theWorld Economy, (Online Paper), Available: http://www.ifw-members.ifwkiel.de/publications/the-solow-model-in-the-empirics-ofgrowth-and-trade/kap1294_revised.pdf(Accessed 24th September 2010, 1317 hours)

[15] Greenaway, D., Morgan, W. and Wright, P. (2001), "Trade Liberalization and Growth inDeveloping Countries", Journal of Development Economics, Vol. 67, pp. 229-244.

[16] Hadjimichael, M., and Ghura, D. (1996), "Growth in SubSaharan Africa", InternationalMonetary Fund, Vol. 43, No. 3, pp. 605-634.

[17] Hsiao, (2007), "Panel Data Analysis-Advantages and Challenges", Institute of Economic Policy Research (IEPR) Working Paper, No. 06/49, pp. 1-22.

[18] Krugman, P. (1983), "New theories of Trade among Industrial Countries", The American Economic Review, Vol. 73, No.2, pp. 343-347.

[19] Krugman, P. (1987), "Is Free Trade Passe?", Journal of Economic Perspectives, Vol. 1, No. 2, pp. 131-144.

[20] Krugman, P. (1994), Rethinking International Trade. London. MIT Press Cambridge. Little, I., Scitovsky, T. and Scott, M. (1970), Industry and Trade in somedeveloping countries: A comparative study. London: Oxford University Press

[21] Longo, R., and Sekkat, K. (2004), "Economic Obstacles to Expanding Intra-AfricanTrade", World Development, Vol. 32, No. 8, pp. 1309-1321.

[22] Morrissey, O., Ackah, C. (2007), "Trade Liberalization is Good for You if You areRich", CREDIT Research Paper, No. 07/01, pp. 1-47.Morrisey, O. and Ackah, C. (2007), "Trade Protection as Income Protection in

[23] PoorCountries", Conference on New Political Economy of Globalization, (Online Paper), Available:(http://www.nottingham.ac.uk/shared/shared leve vents/conferences/2007_tulane_Morrissey_Ackah.pdf (Accessed 16th March 2011, $1 \overline{430}$ hrs)

[24] Morrissey, O., Ackah, C. (2005), "Trade Policy and Performance in Sub-Saharan Africa since the 1980s", CREDIT Research Paper, No. 05/13, pp. 1-39.

[25] Qiu, L. (1994), "Optimal strategic trade policy under asymmetric information", Journal of International Economics, Vol. 36, pp. 333-354.

[26] Ray, D. (1998), Development Economics. Princeton, New Jersey: PrincetonUniversity Press.

[27] Rodrik, D. (1998), "Trade Policy and Economic Performance in Sub-SaharanAfrica",NBER Working Papers, No. W6562, pp. 1-74 (OnlinePaper),Available:http://papers.ssrn.com/sol3/papers. cfm?abstract_id=226295, (Accessed 31st August 2010, 1050 hours).

[28] Rodrik, D. (2001), "Development Strategies for the Next Century", Harvard University Working Papers, (Online Paper),Available:http://www.eclac.cl/prensa/noticias/comuni cados/6/7616/DaniRodrik29-08.pdf (Accessed 31st August 2010, 0930 hours)

[29] Rodriquez, F. and Rodrik, D. (2000), "Trade Policy and Economic Growth: ASkeptic's Guide to the Gross National Evidence", NBER Macroeconomic Annual, Vol. 15, pp. 261-325.

[30] Romer, P. (1986), "Increasing Returns and Long Run Growth", The Journal of Political Economy, Vol. 94, No. 5, pp. 1002-1037.

[31] Romer, P. (1994), "The Origins of Endogenous Growth", The Journal of Economic Perspectives,Vol. 8, No. 1, pp. 322.

[32] Romer, P., Phelps, E. and Mankiw, N. (1995), "Growth of Nations", Brookings Papers onEconomic Activity, No. 1, Vol. 1995, pp. 275-326.

[33] Roodman, D. (2006), "How to xtabond2: An introduction to "Difference" and"System" GMM in Stata",Center for Global Development, Working Paper, No. 103, pp. 1-51.

[34] Saggi, Kamal (2002) "Trade, Foreign Direct Investment and International Technology Transfer: A Survey", The World Bank Research Observer, Vol. 17, No 2.

[35] Schmidt-Hebbel, K., Serven, L. and Solimano, A. (1996), "Savings and Investment: Paradigms, Puzzles and Policies", The World Bank Research Observer, Vol. 11, No. 1, pp. 87117.

[36] Shafaeddin, S. (2005), "Trade liberalization and economic 
reform in developing countries: Structural Change or deindustrialization?" United Nations Working Paper, No. 179, pp. 1-27.

[37] Smith, A. (1776), an Inquiry into the Wealth of Nations. London. The ElectricBook CompanyLtd.,(Online Book), Available: http://www2.hn.psu.edu/faculty/jmanis/adamsmith/Wealth-Nations.pdf(Accessed 24th September 2010 1412 hours).

[38] UNDP (2003), Making global trade work for people. New York and London: EarthscanPublication Ltd.

[39] UNDP (2008),Aid for Trade and Human Development; A guide to Conducting Aid for Trade NeedsAssessment Exercises. New York, United Nations Publications.

[40] World Bank (2004-2011), Doing Business Report, The World Bank Group, (Online Publications), Available:http://www.doingbusiness.org/reports/doingbusiness/doing-business-2004 (Accessed on 15th April,
20111223 hours).

[41] Wacziarg, R. and Welch, K. (2003), "Trade Liberalization and Growth: New Evidence", National Bureau of Economic Research Working Paper, No. 10152, pp. 1-90.

[42] Winters, A. (2004), "Trade Liberalization and Economic Performance: An Overview", TheEconomic Journal, Vol. 114, No.493, pp. F4-F21.

[43] Wooldridge, J. (2001), “Applications of Generalized Method of moments Estimation", The Journal of Economic Perspectives, Vol. 15, No. 4, pp. 87-100.

[44] Vamvakidis, "How Robust is Growth Openness Connection? Historical Evidence", Journal ofEconomic Growth, Vol. 7, pp. $57-80$

[45] Yanikkaya, H. (2002), "International Trade Openness and Economic Growth: ACross Country Empirical Investigation", Journal of Development Economics, Vol. 72, pp. 57-89. 